\title{
The Dynamic Relationship between Managerial Ownership and Corporate Diversification: Evidence for Family and Non-Family Businesses
}

\author{
Tsui-Jung Lin ${ }^{1}$, Li Chang ${ }^{2}$, Chi-Ping $\mathrm{Hou}^{3} \&$ Pei-Rong Chou ${ }^{4}$ \\ ${ }^{1}$ Department of Financial and Banking, Chinese Culture University, Taiwan \\ ${ }^{2}$ Department of Business Administration, Shih Hsin University, Taiwan \\ ${ }^{3}$ Department of Accounting, China University of Technology, Taiwan \\ ${ }^{4}$ Department of Investment, Zurich insurance group, Taiwan \\ Correspondence: Li Chang, Department of Business Administration, Shih Hsin University, 111, Mu-Cha Rd., \\ Taipei 116, Taiwan. Tel: 886-2-2236-8225. E-mail: scottlic@cc.shu.edu.tw
}

Received: February 11, 2014

Accepted: March 6, 2014

Online Published: April 25, 2014

doi:10.5539/ijef.v6n5p84

URL: http://dx.doi.org/10.5539/ijef.v6n5p84

\begin{abstract}
In Taiwan, ownership structure is separated to differentiate between family businesses and non-family businesses. Moreover, the dynamic relationship between managerial ownership and corporate diversification is complicated. This study is attempted to examine, under different ownership structure, whether managerial ownership is associated with subsequent changes in diversification or diversification is associated with subsequent changes in ownership. This study used a sample of firms listed in Taiwan from 2002 to 2011; the Panel Data Regression with fixed effects model is utilized to find the relationship between managerial ownership and diversification. This result shows that in non-family businesses, managerial ownership (diversification) is negatively related to subsequent diversification (subsequent managerial ownership); in family businesses, managerial ownership (diversification) is positively related to subsequent diversification (subsequent managerial ownership). Therefore, investors should understand the business strategy that lead to changes among family business, managerial ownership and diversification in order to facilitate investment decisions.
\end{abstract}

Keywords: managerial ownership, corporate diversification, family businesses, dynamic relationship

\section{Introduction}

Empirical studies in the past supported a negative relationship between managerial ownership and corporate diversification (Denis, Denis, \& Sarin, 1997; Denis, Denis, \& Yost, 2002; Martin, \& Sayrak, 2003; David et al., 2010). This is because, as managerial ownership increases, the consistency between owners and managers of the incentives will also increase, meaning that those managers will not adopt a corporate diversification strategy to decrease the value of the company. Unfortunately, these empirical results are validated based on cross-sectional data, from which it can be concluded that changes of managerial ownership will take place before the behavior of diversification. However, such cross-sectional data validation can not capture the changes in the relationship among the variables that occur over time. Goranova et al. (2007) found that managerial ownership for a period did not result in subsequent changes of diversification and therefore questioned the hypothesis of the interest alignment. The higher the level of diversification, the more positive the relationship with the subsequent changes of managerial ownership, supporting the view of reducing risk by managers. Nevertheless, their conclusions are based on a sample taken from developed countries and the hypothesis agency theory. Indeed, past studies have shown that the traditional agency problem is not serious in developing countries (emerging markets) as in developed countries (Tsai et al., 2006; Delios, Zhou, \& Xu, 2008; Charoenwong, Ding, \& Jiraporn, 2011). Therefore, whether the negative relationship between managerial ownership and diversification based on developed countries can be applied to developing countries, is a question and need to be verified.

Different ownership structures (family business and non-family business) will affect a company's supervision, strategy and performance (Shleifer \& Vishny, 1994; Anderson \& Reeb, 2003b). The family business structure is common in Taiwan; informal effect from family system exceeds the formal influence of the corporate system 
(Liu, Lin, \& Cheng, 2011). In addition, the management style of the family business is family members at the core, making it difficult for non-family managers to promote (Claessens, Djankov, \& Lang, 2000). This phenomenon reflects that family business is difficult to attract good employees, limiting the talent pool, and ultimately blocking the company's growth. As a result, whether the causality between managerial ownership and diversification can be applied to family business in developing countries is also an interesting issue.

The study is attempted to re-examine the dynamic causal relationship between managerial ownership and diversification in Taiwan different ownership companies (family business and non-family business). The purposes of this paper are investigated (1) the relationship between managerial ownership and subsequent changes in corporate diversification under different ownership structures, and (2) the relationship between diversification and subsequent changes in managerial ownership under different ownership structures. As our knowledge, this is the first study to apply dynamic relationship between managerial ownership and diversification in family business in emerging markets. In addition, the findings should also be useful to investors in developed countries who might be planning to enter the Taiwanese and Chinese finance markets (Note 1).

\section{Literature Review}

Incentives alignment from managerial motivation can be effectively increased the company wealth to avoid diversification (Beatty \& Zajac, 1994; Jensen \& Meckling, 1976; Martin \& Sayrak, 2003). Therefore, most previous studies indicated that there is a negative relationship between ownership structure and company diversification (Amihud \& Lev, 1981; Berger \& Ofek, 1995). However, it is difficult to understand the causal relationship among variables because this type of verification can not capture changes in corporate behavior over time (Li, Lam, \& Moy, 2005). In addition, the management member and style are different between the family business and non-family business. If changes in the managerial ownership structure are examined using longitudinal data and the different ownership, we could understand that how changes of the managerial ownership structure affect the dynamic of diversification behavior in family and nonfamily business.

\subsection{Longitudinal Effects of Managerial Ownership on Diversification}

\subsubsection{Non-Family Businesses}

Ddiversification in non-family businesses is an indication of managers pursuing their own interests and risk diversification, but the major shareholders can adopt concentration of ownership to resolve this agency problem (Johnson, 1996; Boyd, Gove, \& Hitt, 2005; Chen \& Hsu, 2009). Bethel and Liebeskind (1993) found that within a period of time there was a negative correlation between the ownership of major shareholders and later diversification. This implies that the monitoring from major shareholders will affect the later level of diversification. Denis, Denis and Sarin (1997) also pointed out that increased managerial ownership would reduce the level of diversification, showing that the monitoring from managerial ownership could reduce later diversification behavior. Also, when managerial ownership is increased, the agency problem of free cash flow will be reduced, as well as the interest alignment will be strengthened (Amihud \& Lev, 1981). Therefore, we expect the following hypothesis:

H 1-1: In non-family businesses, managerial ownership is negatively related to subsequent changes in corporate diversification.

\subsubsection{Family Businesses}

Due to managers and owners in family business are the same (most managers are members of family), the traditional agency theory (Type I) could not apply to family business (Anderson \& Reeb, 2003a; Chrisman, Chua, \& Sharma, 2005; Tsai et al., 2006). However, when the ratio of equity held by family shareholders is large enough for effective control of the company, type II agency problems between controlling and minority shareholders occur. Family shareholders are concerned with the family's interest, rather than those of minority shareholder (Chu, 2009). In order to maximize its own benefits, the family business may take over other shareholders interests exercising controlling power and expropriate the wealth of minority shareholders. In the diversification aspect, it results in good opportunities for speculation and exploitation of the interests of minority shareholders (Claessens, Djankov, \& Lang, 2000; Claessens et al., 2002). Therefore, enlargement of the manager's ownership in the family business will enhance later diversification to exploit the interests of minority shareholders. The hypothesis is as follows:

H 1-2: In family businesses, managerial ownership is positively related to subsequent changes in corporate diversification. 


\subsection{Impact of Diversification on Managerial Ownership}

\subsubsection{Non-Family Businesses}

Managers in non-family business take a tendency to their own benefits and pursue a higher operational risk than the shareholders. From the behavioral agency viewpoint, if the strategy of diversification is aimed at reducing risk, managers should have a positive response and willingness to subsequently increase the level of ownership (Wiseman \& Gomez-Mejia, 1998). They will have more ownership to reflect the willing to take higher risk to get their own interests (Eisenhardt, 1989; Sanders \& Carpenter, 2003). However, managerial motivation to purse value decreasing activities can be effectively reduced by means of incentives alignment (managerial ownership) to engage in the activities which increase the company wealth (Beatty \& Zajac, 1994; Jensen \& Meckling, 1976). Therefore, company diversification and subsequently enhanced managerial ownership would be a negative relation. We expect the following hypothesis:

H 2-1: In non-family businesses, diversification is negatively related to subsequent changes in managerial ownership.

\subsubsection{Family Businesses}

Zahra (2005) showed that managers with family members are more highly motivated to follow a strategy of risk aversion. Furthermore, family business will avoid diversification, because the company is viewed as family member or descendant assets (Casson, 1999; Anderson \& Reeb, 2003b). Schulze, Lubatkin and Dino (2002) have pointed out that the concentration of family businesses ownership may reduce the entrepreneurial spirit, in turn to induce conservative strategies. Therefore, family business managers are more conservative than non-family business management, in relation to diversification strategies. However, family shareholders have greater a motivation and ability to expropriate the wealth of minority shareholders (La Porta et al., 1999). This is the Type II agency problem where controlling shareholders exploit minority shareholders (Shleifer \& Vishny, 1997; Ellul, Guntay, \& Lel, 2007). That is, in family businesses, it is easy to take advantage of their controlling power to make self-benefiting decisions, causing minority shareholders to suffer loss of wealth. Even diversification is a strategy for reducing corporate value, for the family maximum benefits' purpose, family business managers may enlarge the level of diversification for the expropriation (Amihud \& Lev, 1981; Berger \& Ofek, 1995; Hoskisson, Hill, \& Kim, 1993; Lang \& Stulz, 1994). After that, minority shareholders will enforce to sell their stock; family business managers will increase their ownership to enhance control rights of family business. Therefore, when managers of family businesses enlarge the diversification strategy, they will increase their subsequent ownership in order to protect family control right and wealth. Therefore, this study suggests that after diversification, the managerial ownership will be increased. The hypothesis is as follows:

H 2-2: In family businesses, diversification is positively related to subsequent changes in managerial ownership.

\section{Research Methodology}

\subsection{Sample and Model}

The sample in this study is taken from companies listed in Taiwan from 2002 to 2011. The financial and corporate governance information is acquired from the Taiwan Economic Journal (TEJ) database, annual reports and the prospectuses of listed Taiwan companies. The product and industry classification used for computing the indicators of diversification is obtained from the "Industry and Economic" classification structure developed by the Taiwan Institute of Economic Research (TIER) database. This sample is excluded financial industry, insurance industry and banking industry, because of avoiding confounding effect. The sample included around 364 firms list in Taiwan stock market (TSE) during the period of 2002 to 2011, totally 3,642 observations after excluded financial institution data and missing data. In this study, there are a total of 3,642 observations, of which 2,169 (59.55\%) of the observed values are for family firms and 1,473 (40.45\%) of the observed values are non-family firms. In addition, the sample in this study includes both cross-sectional data and time series data. This study adopts panel data analysis (Note 2).

The dynamic relationship between managerial ownership and diversification is modeled and verified. Models 1 , 2,3 and 4 verify hypotheses $1-1$ and 1-2, respectively, representing the dynamic relationship of managerial ownership over a period of time and the subsequent company diversification between family businesses and non-family businesses, formulated as follow: 
Partial sample-family business

$$
\begin{aligned}
& D I V_{i, t}=\alpha_{0}+\alpha_{1} F B O W N_{i, t}+\alpha_{2} \operatorname{LogSIZE}_{i, t}+\alpha_{3} R_{I S K_{i, t}}+\alpha_{4} D E B T_{i, t}+\alpha_{5} I N D_{i, t}+\alpha_{6} R O A_{i, t}+\alpha_{7} D U A L_{i, t} \\
& +\alpha_{8} \text { OUTDIR }_{i, t}+\alpha_{9} \text { DIROWN }_{i, t}+\alpha_{10} B L O C K_{i, t}+\alpha_{11} I_{N S T_{i, t}}+{ }_{\varepsilon i, t} \\
& D I V_{i, t+1}=b_{0}+b_{1} \text { FBOWN }_{i, t}+b_{2} \operatorname{LogSIZE}_{i, t}+b_{3} \text { RISK }_{i, t}+b_{4} \text { DEBT }_{i, t}+b_{5} I N D_{i, t}+b_{6} R O A_{i, t}+b_{7} D U A L_{i, t} \\
& +b_{8} \text { OUTDIR }_{i, t}+b_{9} \text { DIROWN }_{i, t}+b_{10} \text { BLOCK }_{i, t}+b_{1 I} I N S T_{i, t}+v_{i, t}
\end{aligned}
$$

Partial sample-nonfamily business

$$
\begin{aligned}
& D I V_{i, t}=\alpha_{0}+\alpha_{1} N F B O W N_{i, t}+\alpha_{2} \operatorname{LogSIZE}_{i, t}+\alpha_{3} \text { RISK }_{i, t}+\alpha_{4} D E B T_{i, t}+\alpha_{5} I N D_{i, t}+\alpha_{6} R O A_{i, t}+\alpha_{7} D U A L_{i, t} \\
& +\alpha_{8} O_{U T D I R_{i, t}}+\alpha_{9} D_{\text {IROWN }}+\alpha_{10} \text { BLOCK }_{i, t}+\alpha_{11} I_{I N S T_{i, t}}+\varepsilon_{i, t} \\
& D I V_{i, t+1}=b_{0}+b_{1} N_{F B O W N}+N_{i, t} \operatorname{LogSIZE}_{i, t}+b_{3} R_{I S K_{i, t}}+b_{4} D E B T_{i, t}+b_{5} I N D_{i, t}+b_{6} R^{2} O A_{i, t}+b_{7} D U A L_{i, t} \\
& +b_{8} \text { OUTDIR }_{i, t}+b_{9} \text { DIROWN }_{i, t}+b_{10} \text { BLOCK }_{i, t}+b_{11} I_{N S T_{i, t}}+v_{i, t}
\end{aligned}
$$

The dynamic relationship between managerial ownership and diversification is modeled and verified. Models 1 , 2,3 and 4 verify hypotheses $1-1$ and $1-2$, respectively, representing the dynamic relationship of managerial ownership over a period of time and the subsequent company diversification where $D I V_{i, t}$ is company i's level of diversification in the $\mathrm{t}^{\text {th }}$ period; $D I V_{i, t+1}$ is company i's level of diversification in the $\mathrm{t}+1^{\text {th }}$ period; $N F B O W N_{i, t}$ is the executive ownership in a non-family business in the $\mathrm{t}^{\text {th }}$ period; $F B O W N_{i, t}$ is the executive ownership in a family business in the $\mathrm{t}^{\text {th }}$ period; $\operatorname{LogSIZE_{i,t}}$ is the size of company $\mathrm{i}$ in the $\mathrm{t}^{\text {th }}$ period; $R I S K_{i, t}$ is the risk of company $\mathrm{i}$ in the $\mathrm{t}^{\text {th }}$ period; $D E B T_{i, t}$ is the financial leverage of company $\mathrm{i}$ in the $\mathrm{t}^{\text {th }}$ period; $R O A_{i, t}$ is the performance of company $\mathrm{i}$ in the $\mathrm{t}^{\text {th }}$ period; $D U A L_{i, t}$ is the status of company i's CEO duality in the $\mathrm{t}^{\text {th }}$ period; $O U T D I R_{i, t}$ is the ratio of company i's outside board directors in the $\mathrm{t}^{\text {th }}$ period; $D I R O W N_{i, t}$ is the shares held by company i's board directors in the $\mathrm{t}^{\text {th }}$ period; $B L O C K_{i, t}$ is the ratio of share numbers of company i's major shareholders in the $\mathrm{t}^{\text {th }}$ period; $I N S T_{i, t}$ is the ownership of company i's institutional investors in the $\mathrm{t}^{\text {th }}$ period; $I N D_{i, t}$ is the industry category of company $\mathrm{i}$ in the $\mathrm{t}^{\text {th }}$ period; $\varepsilon_{i, t}$ and $v_{i, t}$ are model residuals, while $\varepsilon_{i, t}, v_{i, t} \sim \mathrm{N}(0,1)$.

Models 5 to 8 are used to verify hypotheses 2-1 and 2-2, which represent the relationship of the level of diversification over a period of time and the subsequent managerial ownership between family businesses and non-family businesses. The variables are the same as those defined above.

Partial sample-family business

$$
\begin{aligned}
& F_{B B O W N}{ }_{i, t}=c_{0}+\alpha_{1} D I V_{i, t}+c_{2} \operatorname{LogSIZE}_{i, t}+c_{3} \text { RISK }_{i, t}+\alpha_{4} D E B T_{i, t}+c_{5} I N D_{i, t}+c_{6} R O A_{i, t}+c_{7} D U A L_{i, t} \\
& +c_{8} \text { OUTDIR }_{i, t}+c_{9} \text { DIROWN }_{i, t}+c_{10} B L O C K_{i, t}+c_{11} I N S T_{i, t}+\varepsilon_{i, t}
\end{aligned}
$$

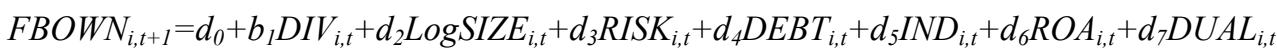

$$
\begin{aligned}
& +d_{8} \text { OUTDIR }_{i, t}+d_{9} \text { DIROWN }_{i, t}+d_{10} \text { BLOCK }_{i, t}+d_{1 I} \operatorname{INST}_{i, t}+v_{i, t}
\end{aligned}
$$

Partial sample-nonfamily business

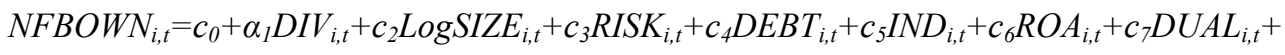

$$
\begin{aligned}
& c_{8} \text { OUTDIR }_{i, t}+c_{9} \text { DIROWN }_{i, t}+c_{10} \text { BLOCK }_{i, t}+c_{11} I N S T_{i, t}+\varepsilon_{i, t} \\
& N_{F B O W N} N_{i, t+1}=d_{0}+d_{1} D_{I} V_{i, t}+d_{2} \operatorname{LogSIZE}_{i, t}+d_{3} R_{I S K_{i, t}}+d_{4} D E B T_{i, t}+d_{5} I N D_{i, t}+d_{6} R O A_{i, t}+d_{7} D U A L_{i, t} \\
& +d_{8} \text { OUTDIR }_{i, t}+d_{9} \text { DIROWN }_{i, t}+d_{10} \text { BLOCK }_{i, t}+d_{11} I N S T_{i, t}+v_{i, t}
\end{aligned}
$$

Where $N F B O W N_{i, t+l}$ is the executive ownership in a non-family business $\mathrm{i}$ in the $\mathrm{t}+1^{\text {th }}$ period. $F B O W N_{i, t+l}$ is the executive's ownership in a family business $\mathrm{i}$ in the $\mathrm{t}^{\text {th }}$ period. $\varepsilon_{i, t}$ and $v_{i, t}$ are model residuals, while $\varepsilon_{i, t} ; v_{i, t} \sim \mathrm{N}(0,1)$.

\subsection{Dependent and Independent Variables}

Level of diversification (DIV) is referred that Palepu (1985) used for calculation of entropy diversification is utilized, and Yang (2008) adopted for calculation of on diversification is used as a template to calculate the level of company diversification.

Due to fact that managers may consider there to be different risk conditions related and unrelated to diversification (Boyd, Gove, \& Hitt, 2005), overall diversification (DT) is divided into two categories: related diversification (DR) and unrelated diversification (DU) (DT=DR+DU). Moreover, Palepu (1985) was defined as the level of diversification in the own products of industry $\mathrm{w}$. The formula is $\mathrm{DR}=\sum_{i-1}^{j} P_{i}^{w} \ln \left(1 / P_{i}^{w}\right)$. Where $\mathrm{j}$ stands for the number of products in an industry $\mathrm{w}, P^{w}{ }_{i}$ is the ratio of sales value for product i in industry w. (DU) is defined as the extent of company products across different industries $(\mathrm{w}=1, \ldots \mathrm{z})$; the measurement is the average weight of all industries' ratio of sales and can be formulated follows: $\mathrm{DU}=\sum_{w-1}^{z} P^{w} \ln \left(1 / P^{w}\right)$. 
Therefore, level of diversification (DIV) is used overall diversification (DT) to be a proxy.

In addition, Managerial ownership is OWN. Moreover, the ownership of family managers and the ownership of non-family managers are indicated by FBOWN, and NFBOWN.

Moreover, managerial ownership is measured by the number of outstanding shares held by managers and the ratio of shares held by managers to total shares. It has been found in previous studies that the value of the company is positively correlated with size and diversification (Denis, Denis, \& Sarin, 1997; Grant, Jammine, \& Thomas, 1998). Thus, if other conditions remain unchanged, the value of one percent of shares is likely to be higher for a diversified company is likely to be higher for a focused company. The percentage of equity which is claimed by signal theory; the reliability of the signal is correlated with the cost of the signal (Spence, 1973). Family business judgments are the number of seats on the board directors occupied by the family members are used as the criteria for judging who has "ultimate control", which made based on the definition of La Porta et al. (1999) and Yeh, Lee and Woidtke (2001). Family business is indicated by the dummy variable "1", while non-family business is set to be " 0 ".

\subsection{Control Variables}

According to literature review, we selected company size (SIZE), business risk (RISK), financial leverage (DEBT), CEO duality (DUAL), board director ownership (DIROWN), percentage of shares held by major shareholders (BLOCK), institutional investor ownership (INST) and industry category (IND) to be control variables (Shleifer \& Vishny, 1986; Lang \& Stulz, 1994; Berger \& Ofek, 1995; Cho, 1998; Mansi \& Reeb, 2002; Wright et al., 2002).

The variable of company size (SIZE) is defined that a log of total assets; this study uses the standard deviation of ROA over the past 3 years to measure business risk (RISK); financial leverage (DBET) is defined total liabilities divided by total assets; the return on assets for the previous year (ROA) is used to measure prior performance $(\mathrm{ROA}=($ Net income + interest expenses $) \times(1-$ tax rate $) /$ average total assets $)$; this study sets CEO duality (DUAL) is dummy variable which DUAL is set as 1 , whereas 0 ; the ratio of outside director seats (OUTDIR) is the number of outside board directors by the end of the previous year divided to the total number of board directors (outside directors are defined as those not-employed by the company, or non-board members of affiliates companies, including employees, or spouses and relatives within the second degree of consanguinity); board of director ownership (DIROWN) is defined as the percentage of outstanding shares held by the board of director; percentage of shareholding held by major shareholders (BLOCK) is measured the ratio of the number of shares held by major shareholders to the total number of outstanding shares (according to the Taiwan Securities and Exchange Act, major shareholders are defined as individuals holding more than $10 \%$ of shares); institutional investor ownership (INST) is defined as the percentage of outstanding shares held by the board of director; industry category is the dummy variable, which is set to be 1 , otherwise 0 .

\section{Empirical Result}

\subsection{Univariate Analysis}

Table 1 shows the calculated descriptive statistics for all variables, and the mean differences $t$ test and nonparametric Mann-Whitney $U$ test results for family and non-family variable differences. The results showed that the diversification index (DIV) for total sample mean (median) of $0.478(0.480)$. Also, the mean (median) for diversified family business is $0.497(0.510)$ which is more than the mean for non-family business for 0.458 $(0.450)$. There are significant differences in diversification index (DIV) between family and non-family business. It implies that family business enhances diversification more than non-family business. In addition, the mean (median) for managerial ownership (OWN) is $2.870(0.925)$; the mean (median) for managerial ownership in family businesses is 3.167 (1.080) which is greater than the mean for managerial ownership in non-family businesses. It shows significant differences in managerial ownership between family and non family business. The control variables, included company size (SIZE), business risk (RISK), financial leverage (DEBT), industry category (IND), prior performance (ROA), CEO duality (DUAL), the percentage of outside board directors (OUTDIR), board director ownership (DIROWN), percentage of shares held by major shareholders (BLOCK) and institutional investors' ownership (INST), are significant difference between the family and non-family samples.

The Pearson correlation coefficient matrix for of the variables is shown in Table 2. The diversification (DIV) and family variables (FB) are significantly positively correlated (0.045), while the levels of diversification (DIV) and managerial ownership $(\mathrm{OWN})$ are negatively correlated $(-0.012)$, but not significant. The largest correlation coefficients for the remaining variables are company size (SIZE) and institutional investor ownership (INST), 
with a value of 0.492 . In addition, this study computed the Variance Inflation Factors (VIF) which shows all variables are all less than 10 , indicating negligible multicollinearity problems.

\subsection{Multivariate Analysis}

\subsubsection{Measurement of the Impact of Managerial Ownership on the Subsequent Diversification}

Table 3 shows the results obtained using panel data regression analysis for models 1, 2, 3 and 4. First, we examine the impact of key variables on diversification in the $\mathrm{t}^{\text {th }}$ period. It is found that there is an insignificant relationship between business ownership and subsequent diversification. However, in the $t+1^{\text {th }}$ period, there is a significant negative correlative between non-family business ownership and subsequent diversification, and family business ownership shows a significant positive correlation with the subsequent diversification, consistent with hypothesis 1-1 and 1-2. In addition, this means that there exists a deferred effect between managerial ownership and diversification in the $\mathrm{t}^{\text {th }}$ and $\mathrm{t}+1^{\text {th }}$ period.

Moreover, the significant negative correlation between non-family business ownership and subsequent diversification means the higher level of the managerial ownership, the interests linked to the owners, and the less the destructive behavior for company value, consistent with Denis, Denis and Sarin (1997). Meanwhile, the greater ownership will offset the managerial benefit received from diversification. Therefore, a higher level of ownership will lead to a lower level of diversification behavior. In addition, the positive correlation, which reaches significant levels between the ratio of family business ownership and subsequent diversification, indicates that in the family business the wealth of minority shareholders may be exploited as family members seek to maximize their own interests. Although diversification may reduce the value of the company, the controlling power and claims right of earnings distribution have a greater deviation in Taiwan, because of complicated pyramidal structure and cross-holdings of family businesses, and weak protection of investors and minority shareholders. Therefore, family business uses diversification to exploit minority shareholders. This means that when the level of manager ownership in the family business is enlarged, the level of the diversification will be increased.

Table 1. Descriptive statistics

\begin{tabular}{|c|c|c|c|c|c|c|c|c|}
\hline \multirow[b]{2}{*}{ Variable } & \multirow[b]{2}{*}{$\begin{array}{l}\text { Total } \\
\text { Sample }\end{array}$} & \multicolumn{3}{|c|}{ Mean } & \multicolumn{3}{|c|}{ Median } & \multirow[b]{2}{*}{$\begin{array}{l}\text { Mann-Whitney } \\
\text { U test--z value }\end{array}$} \\
\hline & & $\begin{array}{l}\text { Family } \\
\text { Sample }\end{array}$ & $\begin{array}{l}\text { Non-Family } \\
\text { Sample }\end{array}$ & t-test & $\begin{array}{l}\text { Total } \\
\text { Sample }\end{array}$ & $\begin{array}{l}\text { Family } \\
\text { Sample }\end{array}$ & $\begin{array}{l}\text { Non-Family } \\
\text { Sample }\end{array}$ & \\
\hline DIV & 0.478 & 0.497 & 0.458 & $2.831 * * *$ & 0.480 & 0.510 & 0.450 & $-3.375^{* * *}$ \\
\hline OWN & 2.870 & 3.167 & 2.572 & $3.852 * * *$ & 0.925 & 1.080 & 0.770 & $-1.856^{*}$ \\
\hline SIZE & 3.676 & 3.645 & 3.707 & $-2.876^{* * *}$ & 3.631 & 3.577 & 3.685 & $-4.220 * * *$ \\
\hline RISK & 4.143 & 3.696 & 4.591 & $-6.520 * * *$ & 2.910 & 2.626 & 3.193 & $-5.997 * * *$ \\
\hline DEBT & 0.445 & 0.445 & 0.446 & -0.126 & 0.454 & 0.455 & 0.452 & -0.044 \\
\hline IND & 0.482 & 0.617 & 0.348 & $17.481^{* * *}$ & 0.500 & 1.000 & 0.000 & $-16.859 * * *$ \\
\hline ROA & 5.792 & 5.807 & 5.776 & 0.090 & 5.550 & 5.120 & 5.980 & $-2.283^{* *}$ \\
\hline DUAL & 0.293 & 0.250 & 0.335 & $-5.824 * * *$ & 0.000 & 0.000 & 0.000 & $-5.800 * * *$ \\
\hline OUTDIR & 0.351 & 0.289 & 0.412 & $-17.585^{* * *}$ & 0.358 & 0.286 & 0.429 & $-16.961 * * *$ \\
\hline DIROWN & 0.200 & 0.250 & 0.149 & $24.106^{* * *}$ & 0.174 & 0.221 & 0.126 & $-25.742 * * *$ \\
\hline BLOCK & 1.718 & 2.581 & 0.856 & $8.026 * * *$ & 0.000 & 0.000 & 0.000 & $-8.924 * * *$ \\
\hline INST & 38.553 & 42.736 & 34.370 & $11.469^{* * *}$ & 36.098 & 40.995 & 31.200 & $-10.879 * * *$ \\
\hline Observations & 3,642 & 2,169 & 1,473 & & 3,642 & 2,169 & 1,473 & \\
\hline
\end{tabular}

Note. ${ }^{*}$ indicates the $10 \%$ significance level; $* *$ indicates the $5 \%$ significance level; $* *$ indicates the $1 \%$ significance level; DIV: Diversification; FB: Family Businesses; OWN: Managerial Ownership; SIZE: Company Size; RISK: Business Risk; DEBT: Financial Leverage; IND: Industry Category; ROA: Prior Performance; DU AL: CEO Duality; OUTDIR: Percentage of Outside Directors; DIROWN: Board Director Ownership; BLOCK: Percentage of Shares Held by Major Shareholders; INST: Institutional Investor Ownership. 
Table 2. Pearson correlation (full sample)

\begin{tabular}{lllllll}
\hline \multicolumn{1}{l}{ DIV } & FB & OWN & SIZE & RISK & DEBT \\
\hline DIV & 1 & & & & & \\
FB & $0.045^{* *}$ & 1 & & & & \\
OWN & -0.012 & $0.061^{* *}$ & 1 & & & \\
SIZE & 0.017 & $-0.046^{* *}$ & $-0.176^{* *}$ & 1 & & \\
RISK & $-0.061^{* *}$ & $-0.103^{* *}$ & 0.009 & $-0.077^{* *}$ & 1 & \\
DEBT & $0.070^{* *}$ & -0.002 & $-0.087^{* *}$ & $-0.101^{* *}$ & $0.045^{* *}$ & 1 \\
IND & $0.068^{* *}$ & $0.265^{* *}$ & $-0.066^{* *}$ & $-0.141^{* *}$ & $-0.199^{* *}$ & $0.112^{* *}$ \\
ROA & 0.008 & 0.001 & $0.046^{* *}$ & $0.440^{* *}$ & $-0.070^{*}$ & $-0.317^{* *}$ \\
DUAL & $-0.035^{*}$ & $-0.092^{* *}$ & $0.411^{* *}$ & $-0.118^{* *}$ & $0.035^{*}$ & -0.019 \\
OUTDIR & $-0.034^{*}$ & $-0.274^{* *}$ & $0.064^{* *}$ & $-0.053^{* *}$ & $0.045^{* *}$ & $-0.075^{* *}$ \\
DIROWN & $0.047^{* *}$ & $0.357^{* *}$ & $0.083^{* *}$ & 0.008 & -0.020 & $-0.046^{* *}$ \\
BLOCK & -0.018 & $0.126^{* *}$ & 0.002 & $-0.070^{* *}$ & 0.021 & $0.047^{* *}$ \\
INST & 0.000 & $0.179^{* *}$ & $-0.301^{* *}$ & $0.492^{* *}$ & $-0.053^{* *}$ & -0.018 \\
\hline
\end{tabular}

Table 2. Continued

\begin{tabular}{|c|c|c|c|c|c|c|c|}
\hline & IND & ROA & DUAL & OUTDIR & DIROWN & BLOCK & INST \\
\hline \multicolumn{8}{|l|}{ DIV } \\
\hline \multicolumn{8}{|l|}{ FB } \\
\hline \multicolumn{8}{|l|}{ OWN } \\
\hline \multicolumn{8}{|l|}{ SIZE } \\
\hline \multicolumn{8}{|l|}{ RISK } \\
\hline \multicolumn{8}{|l|}{ DEBT } \\
\hline IND & 1 & & & & & & \\
\hline ROA & $-0.126^{* *}$ & 1 & & & & & \\
\hline DUAL & $-0.082 * *$ & $-0.061 * *$ & 1 & & & & \\
\hline OUTDIR & $-0.215^{* *}$ & $0.106^{* *}$ & $0.040^{*}$ & 1 & & & \\
\hline DIROWN & $0.051 * *$ & $0.119^{* *}$ & $-0.121 * *$ & 0.021 & 1 & & \\
\hline BLOCK & $0.093^{* *}$ & $-0.072 * *$ & 0.010 & -0.024 & $-0.068^{* *}$ & 1 & \\
\hline INST & $0.056^{* *}$ & $0.263 * *$ & $-0.156^{* *}$ & 0.028 & $0.420^{* *}$ & $0.163^{* *}$ & 1 \\
\hline
\end{tabular}

Note. * When the significance level is at 0.05 (two-tailed), it will be significantly relevant; ** When the significance level is at 0.01 (two-tailed), it will be significantly relevant; DIV: Diversification; FB: Family Businesses; OWN: Managerial Ownership; SIZE : Company Size; RISK: Business Risk; DEBT: Financial Leverage; IND : Industry Category; ROA: Prior Performance; DU AL: CEO Duality; OUTDIR: Percentage of Outside Directors; DIROWN: Board Director Ownership; BLOCK : Percentage of Shares Held by Major Shareholders; INST: Institutional Investor Ownership.

Table 3. The relationship between managerial ownership and subsequent diversification

\begin{tabular}{lllll}
\hline & \multicolumn{2}{c}{ Family (FB) } & \multicolumn{2}{c}{ Non-Family (NFB) } \\
Variable & DIV t ${ }^{\text {th }}$ period & DIV t $+1^{\text {th }}$ period & DIV th period $^{\text {th }}$ period \\
\hline C & $0.216^{* *}$ & $0.431^{* * *}$ & $0.221^{* *}$ & $0.445^{* * *}$ \\
FBOWN/NFBOWN & $(2.003)$ & $(5.125)$ & $(2.046)$ & $(5.292)$ \\
& $-\mathbf{0 . 0 0 1}$ & $\mathbf{0 . 0 0 3 * *}$ & $\mathbf{- 0 . 0 0 2}$ & $-\mathbf{0 . 0 0 3 * *}$ \\
SIZE & $(-0.379)$ & $(2.220)$ & $(-1.001)$ & $(-2.348)$ \\
& 0.039 & 0.000 & 0.038 & -0.002 \\
RISK & $(1.375)$ & $(0.005)$ & $(1.363)$ & $(-0.076)$ \\
& 0.000 & 0.000 & 0.000 & 0.000 \\
DEBT & $(0.173)$ & $(0.124)$ & $(0.186)$ & $(0.123)$ \\
& $0.103 *$ & $0.057^{*}$ & $0.101^{*}$ & $0.055^{*}$ \\
ROA & $(1.810)$ & $(1.667)$ & $(1.770)$ & $(1.795)$ \\
& 0.000 & 0.000 & 0.000 & 0.000 \\
DUAL & $(0.114)$ & $(0.477)$ & $(0.120)$ & $(0.473)$ \\
& -0.006 & -0.006 & -0.005 & -0.004 \\
& $(-0.361)$ & $(-0.506)$ & $(-0.311)$ & $(-0.291)$ \\
\hline
\end{tabular}




\begin{tabular}{lllll}
\hline OUTDIR & 0.020 & -0.030 & 0.023 & -0.031 \\
& $(0.703)$ & $(-1.418)$ & $(0.798)$ & $(-1.487)$ \\
DIROWN & $0.250^{* *}$ & $0.205^{* * *}$ & $0.245^{* *}$ & $0.216^{* * *}$ \\
& $(2.585)$ & $(2.866)$ & $(2.566)$ & $(3.008)$ \\
BLOCK & $-0.001^{*}$ & $-0.002^{*}$ & $-0.001 *$ & $-0.002^{*}$ \\
& $(-1.669)$ & $(-1.788)$ & $(-1.695)$ & $(-1.808)$ \\
INST & 0.001 & 0.001 & 0.001 & 0.001 \\
& $(0.841)$ & $(0.480)$ & $(0.767)$ & $(0.404)$ \\
$\mathrm{R}^{2}$ & 0.753 & 0.903 & 0.762 & 0.914 \\
Adj. $\mathrm{R}^{2}$ & 0.732 & 0.894 & 0.733 & 0.894 \\
F value & $15.533^{* * *}$ & $39.103 * * *$ & $15.539 * * *$ & $39.070^{* * *}$ \\
Observations & 3642 & 3048 & 3642 & 3048 \\
\hline
\end{tabular}

Note. * When the significance level is at 0.10 , it will be significantly relevant; ** When the significance level is at 0.05 , it will be significantly relevant; ${ }^{* *}, *$ When the significance level is at 0.01 , it will be significantly relevant; FB: Family Businesses; NFB: Nonfamily Business; DIV: Diversification; FBOWN: Family Businesses Managerial Ownership; NFBOWN: Nonfamily Businesses Managerial Ownership; SIZE :Company Size; RISK: Business Risk; DEBT: Financial Leverage; IND :Industry Category; ROA: Prior Performance; DU AL: CEO Duality; OUTDIR: Percentage of Outside Directors; DIROWN: Board Director Ownership; BLOCK : Percentage of Shares Held by Major Shareholders; INST: Institutional Investor Ownership.

\subsubsection{Measurement of the Impact of Diversification on the Subsequent Managerial Ownership}

Table 4. The relationship between diversification and subsequent managerial ownership

\begin{tabular}{|c|c|c|c|c|}
\hline \multirow[b]{2}{*}{ Variable } & \multicolumn{2}{|c|}{ Family (FB) } & \multicolumn{2}{|c|}{ Non-family (NFB) } \\
\hline & $\begin{array}{l}\text { FBOWN } t^{\text {th }} \\
\text { period }\end{array}$ & $\begin{array}{l}\text { FBOWN t }+1^{\text {th }} \\
\text { period }\end{array}$ & $\begin{array}{l}\text { NFBOWN } t^{\text {th }} \\
\text { period }\end{array}$ & $\begin{array}{l}\text { NFBOWN t }+1^{\text {th }} \\
\text { period }\end{array}$ \\
\hline $\mathrm{C}$ & -1.300 & $3.290 * *$ & $1.717^{* *}$ & $1.749^{*}$ \\
\hline & $(-1.062)$ & $(2.206)$ & $(1.997)$ & $(1.667)$ \\
\hline DIV & $\begin{array}{l}-\mathbf{- 0 . 0 7 9} \\
(-0.379)\end{array}$ & $\begin{array}{l}\mathbf{0 . 8 0 4 * *} \\
(2.220)\end{array}$ & $\begin{array}{l}\mathbf{- 0 . 1 4 7} \\
(-1.001)\end{array}$ & $\begin{array}{l}-\mathbf{- 0 . 4 4 5 * *} \\
(-2.248)\end{array}$ \\
\hline SIZE & $\begin{array}{l}0.299 \\
(0.935)\end{array}$ & $\begin{array}{l}0.747^{*} \\
(1.959)\end{array}$ & $\begin{array}{l}-0.061 \\
(-0.273)\end{array}$ & $\begin{array}{l}0.062 \\
(0.231)\end{array}$ \\
\hline RISK & $\begin{array}{l}-0.011 \\
(-0.697)\end{array}$ & $\begin{array}{l}0.000 \\
(0.011)\end{array}$ & $\begin{array}{l}0.005 \\
(0.451)\end{array}$ & $\begin{array}{l}-0.000 \\
(-0.029)\end{array}$ \\
\hline DEBT & $\begin{array}{l}1.216^{*} \\
(1.884)\end{array}$ & $\begin{array}{l}0.388^{*} \\
(1.670)\end{array}$ & $\begin{array}{l}-0.668^{*} \\
(-1.772)\end{array}$ & $\begin{array}{l}-1.301 * * \\
(-2.480)\end{array}$ \\
\hline ROA & $\begin{array}{l}0.011 \\
(1.251)\end{array}$ & $\begin{array}{l}-0.000 \\
(-0.007)\end{array}$ & $\begin{array}{l}0.005 \\
(0.833)\end{array}$ & $\begin{array}{l}-0.000 \\
(-0.116)\end{array}$ \\
\hline DUAL & $\begin{array}{l}1.945^{* * *} \\
(10.006)\end{array}$ & $\begin{array}{l}0.783^{* * *} * \\
(3.472)\end{array}$ & $\begin{array}{l}0.920 * * * \\
(6.739)\end{array}$ & $\begin{array}{l}0.259^{*} \\
(1.683)\end{array}$ \\
\hline OUTDIR & $\begin{array}{l}-0.933 * * * \\
(-2.872)\end{array}$ & $\begin{array}{l}-0.376 \\
(-1.005)\end{array}$ & $\begin{array}{l}-0.947 * * * \\
(-4.151)\end{array}$ & $\begin{array}{l}-0.166 \\
(-0.631)\end{array}$ \\
\hline DIROWN & $\begin{array}{l}9.094 * * * \\
(8.395)\end{array}$ & $\begin{array}{l}2.078 \\
(1.640)\end{array}$ & $\begin{array}{l}0.362 \\
(0.476)\end{array}$ & $\begin{array}{l}1.643^{*} \\
(1.842)\end{array}$ \\
\hline BLOCK & $\begin{array}{l}0.050 * * * \\
(3.858)\end{array}$ & $\begin{array}{l}-0.032 * * \\
(-2.323)\end{array}$ & $\begin{array}{l}-0.002 \\
(-0.255)\end{array}$ & $\begin{array}{l}-0.023 * * \\
(-2.021)\end{array}$ \\
\hline INST & $\begin{array}{l}-0.015^{* *} \\
(-2.463)\end{array}$ & $\begin{array}{l}-0.005^{*} \\
(-1.764)\end{array}$ & $\begin{array}{l}-0.021 * * * \\
(-4.853)\end{array}$ & $\begin{array}{l}-0.015 * * * \\
(-3.071)\end{array}$ \\
\hline $\mathrm{R}^{2}$ & 0.695 & 0.674 & 0.603 & 0.587 \\
\hline Adj. $R^{2}$ & 0.650 & 0.637 & 0.566 & 0.530 \\
\hline$F$ value & $10.837 * * *$ & $8.909 * * *$ & $7.910 * * *$ & $6.087 * * *$ \\
\hline Observations & 3642 & 3048 & 3642 & 3048 \\
\hline
\end{tabular}

Note. * When the significance level is at 0.10 , it will be significantly relevant; ** When the significance level is at 0.05 , it will be significantly relevant; $* *,{ }^{*}$ When the significance level is at 0.01 , it will be significantly relevant; FB: Family Businesses; NFB: Nonfamily Business; FBOWN: Family Businesses Managerial Ownership; NFBOWN: Nonfamily Businesses Managerial Ownership; DIV: Diversification; SIZE : Company Size; RISK: Business Risk; DEBT: Financial Leverage; IND : Industry Category; ROA: Prior Performance; DU AL: CEO Duality; OUTDIR: Percentage of Outside Directors; DIROWN: Board Director Ownership; BLOCK : Percentage of Shares Held by Major Shareholders; INST: Institutional Investor Ownership.

Table 4 shows that the panel data regression analysis results for models 5, 6, 7 and 8 . First, when we look at the impact of the major variable on managerial ownership, only in $t+1^{\text {th }}$ period, there is a negative and significant 
correlation between non-family business diversification and subsequent managerial ownership, and is a positive significant correlation in family business, consistent with hypothesis 2-1 and 2-2. In addition, this means that there exists a deferred effect between diversification and managerial ownership in the $\mathrm{t}^{\text {th }}$ and $\mathrm{t}+1^{\text {th }}$ period.

Moreover, the significantly negative correlation between non-family business diversification and subsequent managerial ownership indicates that if a diversification strategy is carried out to strengthen the reputation in the company, this will undermine the value of the business. This means that managers will reduce their level of ownership in order to avoid damaging personal interests. This means that managers will have not a positive linkage to increase the level of ownership managers in order to higher diversification. Thus, this implies the higher the level of diversification in non-family businesses and the lower the degree of managerial ownership. In addition, the significantly positive correlation between family business diversification and subsequent managerial ownership reveals that family business managers increase their ownership to increase control rights of family business after minority shareholders will sell their stock. Thus, in order to strengthen the status of the family business, the amount of managerial ownership will be enlarged after diversification.

\section{Conclusion}

This study investigates the dynamic relationship between managerial ownership and diversification under different ownership structures.

The empirical results show that in non-family business the impact of managerial ownership on the subsequent diversification is significant negative and support the hypothesis 1-1 in this study. This implies that the increased managerial ownership leads to less subsequently destructive company value for avoiding personal interest risk. In family businesses, managerial ownership is positively correlated to the subsequent diversification, consistent with hypothesis 1-2. This indicates that family business managers will enlarge the level of diversification in order to exploit minority shareholders, because family members' wealth is concentrated in family business.

Diversification is significantly negatively correlated with subsequent managerial ownership in non-family businesses. This means that managers will reduce their level of ownership in order to avoid damaging personal interests. In contrast, diversification is significantly positively related to the subsequent managerial ownership in family businesses. It can be inferred that, since the family regards the business as an asset which could be passed on to their descendants, the survival of the business is the primary objective. However, to avoid diversification to exploit minority shareholders, minority shareholders will decrease right, as a result, family business managers will increase their ownership after diversification.

The findings of this study provide several implications for companies, investors and governments. First, for firms, the relationship between managerial ownership and diversification will change over time. Moreover, in the family business, diversification may be a good tool for preserving interests for next generations and for speculation and exploitation of the interests of minority shareholders. Second, for perspective investors, they should understand family businesses and non-family businesses both have different dynamic relationships between managerial ownership and diversification, in order to facilitate investment decisions. Third, government might establish a sound monitor system to watch the change of managerial ownership and diversification (especially, the family business), as well as announce them periodically.

\section{References}

Anderson, R. C., \& Reeb, D. M. (2003a). Founding-family ownership and firm performance: Evidence from the S\&P 500. Journal of Finance, 58(3), 1301-1327. http://dx.doi.org/10.1111/1540-6261.00567

Anderson, R. C., \& Reeb, D. M. (2003b). Founding-family ownership, corporate diversification, and firm leverage. Journal of Law and Economics, 46(2), 653-684. http://dx.doi.org/10.1086/377115

Amihud, Y., \& Lev, B. (1981). Risk reduction as a managerial motive for conglomerate mergers. Bell Journal of Economics, 12(2), 605-617. http://dx.doi.org/10.2307/3003575

Beatty, R. P., \& Zajac, E. J. (1994). Managerial incentives, monitoring, and risk bearing: a study of executive compensation, ownership, and board structure in initial public offerings. Administrative Science Quarterly, 39(2), 313-335. http://dx.doi.org/10.2307/2393238

Berger, P. G., \& Ofek, E. (1995). Diversification's effect on firm value. Journal of Financial Economics, 37(1), 39-65. http://dx.doi.org/10.1016/0304-405X(94)00798-6

Bethel, J. E., \& Liebeskind, J. (1993). The effects of ownership structure on corporate restructuring. Strategic Management Journal, 14(1), 15-31. http://dx.doi.org/10.1002/smj.4250140904

Boyd, B. K., Gove, S., \& Hitt, M. A. (2005). Consequences of measurement problems in strategic management 
research: the case of Amihud and Lev. Strategic Management Journal, 26(4), 367-375. http://dx.doi.org/10.1002/smj.445

Charoenwong, C., Ding, D. K., \& Jiraporn, P. (2011). Corporate diversification, managerial ownership, and firm value: Evidence from the Thai financial crisis. SSRN working paper.

Casson, M. (1999). The economics of the family firm. Scandinavian Economic History Review, 47(1), 10-23. http://dx.doi.org/10.1080/03585522.1999.10419802

Chrisman, J. J., Chua, J. H., \& Sharma, P. (2005). Trends and directions in the development of a strategic management theory of the family firm. Entrepreneurship Theory and Practice, 29(5), 555-576. http://dx.doi.org/10.1111/j.1540-6520.2005.00098.x

Claessens, S., Djankov, S., \& Lang, L. H. (2000). The separation of ownership and control in East Asian corporations. Journal of Financial Economics, $58(1-2), \quad 81-112$. http://dx.doi.org/10.1016/S0304-405X(00)00067-2

Claessens, S., Djankov, S., Fan, J. P., \& Lang, L. H. (2002). Disentangling the incentive and entrenchment effects of large shareholdings. Journal of Finance, 57(6), 2741-2771. http://dx.doi.org/10.1111/1540-6261.00511

Chen, H. L., \& Hsu, W. T. (2009). Family ownership, board independence, and R\&D investment. Family Business Review, 22(4), 347-362. http://dx.doi.org/10.1177/0894486509341062

Cho, M. H. (1998). Ownership structure, investment, and the corporate value: An empirical analysis. Journal of Financial Economics, 47(1), 103-121. http://dx.doi.org/10.1016/S0304-405X(97)00039-1

Chu, W. (2009). The influence of family ownership on SME performance: evidence from public firms in Taiwan. Small Business Economics, 33(3), 353-373. http://dx.doi.org/10.1007/s11187-009-9178-6

David, P., O'brien, J. P., Yoshikawa, T., \& Delios, A. (2010). Do shareholders or stakeholders appropriate the rents from corporate diversification? The influence of ownership structure. Academy of Management Journal, 53(3), 636-654. http://dx.doi.org/10.5465/AMJ.2010.51469005

Delios, A., Zhou, N., \& Xu, W. W. (2008). Ownership structure and the diversification and performance of publicly-listed companies in China. Business Horizons, 51(6), 473-483. http://dx.doi.org/10.1016/j.bushor.2008.06.004

Denis, D. J., Denis, D. K., \& Sarin, A. (1997). Agency problems, equity ownership, and corporate diversification. Journal of Finance, 52(1), 135-159. http://dx.doi.org/10.1111/j.1540-6261.1997.tb03811.x

Denis, D. J., Denis, D. K., \& Yost, K. (2002). Global diversification, industrial diversification, and firm value. Journal of Finance, 57(5), 1951-1979. http://dx.doi.org/10.1111/0022-1082.00485

Eisenhardt, K. M. (1989). Agency theory: An assessment and review. Academy of Management Review, 14(1), $57-74$.

Ellul, A., Guntay, L., \& Lel, U. (2007). External governance and debt agency costs of family firms. International Finance Discussion Papers, Indiana University.

Goranova, M., Alessandri, T. M., Brandes, P., \& Dharwadkar, R. (2007). Managerial ownership and corporate diversification: a longitudinal view. Strategic Management Journal, 28(3), 211-225. http://dx.doi.org/10.1002/smj.570

Grant, R. M., Jammine, A. P., \& Thomas, H. (1988). Diversity, diversification, and profitability among British Manufacturing Companies, 1972-1984. Academy of Management Journal, 31(4), 771-801. http://dx.doi.org/10.2307/256338

Hoskisson, R. E., Hill, C. W., \& Kim, H. (1993). The multidivisional structure: organizational fossil or source of value? Journal of Management, 19(2), 269-298. http://dx.doi.org/10.1016/0149-2063(93)90055-R

Hoskisson, R. E., Johnson, R. A., \& Moesel, D. D. (1994). Corporate divestiture intensity in restructuring firms: effects of governance, strategy, and performance. Academy of Management Journal, 37(5), 1207-1251. http://dx.doi.org/10.2307/256671

Jensen, M. C., \& Meckling, W. H. (1976). Theory of the firm: Managerial behavior, agency costs and ownership $\begin{array}{lllll}\text { structure. Journal of } & \text { Financial 305-360. }\end{array}$ http://dx.doi.org/10.1016/0304-405X(76)90026-X

Johnson, R. A. (1996). Antecedents and outcomes of corporate refocusing. Journal of Management, 22(3), 439- 
483. http://dx.doi.org/10.1177/014920639602200304

La Porta, R., Lopez-de-Silanes, F., \& Schleifer, A. (1999). Corporate ownership around the world. Journal of Finance, 54(2), 471-517. http://dx.doi.org/10.1111/0022-1082.00115

Lang, L. H., \& Stulz, R. M. (1994). Tobin's q, corporate diversification, and firm performance. Journal of Political Economy, 102, 1248-1280. http://dx.doi.org/10.1086/261970

Li, J., Lam, K., \& Moy, J. W. (2005). Ownership reform among state firms in China and its implications. Management Decision, 43(4), 568-588. http://dx.doi.org/10.1108/00251740510593567

Liu, Y., Lin, W. T., \& Cheng, K. Y. (2011). Family ownership and the international involvement of Taiwan's high-technology firms: The moderating effect of high-discretion organizational slack. Management and Organization Review, 7(2), 201-222. http://dx.doi.org/10.1111/j.1740-8784.2011.00220.x

Martin, J. D., \& Sayrak, A. (2003). Corporate diversification and shareholder value: A survey of recent literature. Journal of Corporate Finance, 9(1), 37-57. http://dx.doi.org/10.1016/S0929-1199(01)00053-0

Mansi, S. A., \& Reeb, D. M. (2002). Corporate diversification: What gets discounted? Journal of Finance, 57(5), 2167-2183. http://dx.doi.org/10.1111/0022-1082.00492

Palepu, K. (1985). Diversification strategy, profit performance, and the entropy measure. Strategic Management Journal, 6(3), 239-255. http://dx.doi.org/10.1002/smj.4250060305

Sanders, W. G., \& Carpenter, M. A. (2003). Strategic satisfying? A behavioral—agency theory perspective on stock repurchase program announcements. Academy of Management Journal, 46(2), 160-178. http://dx.doi.org/10.2307/30040612

Schulze, W. S., Lubatkin, M. H., \& Dino, R. N. (2002). Altruism, agency, and the competitiveness of family firms. Managerial and Decision Economics, 23(4-5), 247-259. http://dx.doi.org/10.1002/mde.1064

Shleifer, A., \& Vishny, R. W. (1986). Large shareholders and corporate control. Journal of Political Economy, 94(3), 461-4898. http://dx.doi.org/10.1086/261385

Shleifer, A., \& Vishny, R. W. (1994). Politicians and Firms. The Quarterly Journal of Economics, 109(4), 9951025. http://dx.doi.org/10.2307/2118354

Shleifer, A., \& Vishny, R. W. (1997). A survey of corporate governance. Journal of Finance, 25, 737-783. http://dx.doi.org/10.1111/j.1540-6261.1997.tb04820.x

Spence, M. (1973). Market Signaling. Quarterly Journal of Economics, 87(3), 355-374. http://dx.doi.org/10.2307/1882010

Tsai, W. H., Hung, J. H., Kuo, Y. C., \& Kuo, L. (2006). CEO tenure in Taiwanese family and non-family firms: An agency theory perspective. Family Business Review, 19(1), 11-28. http://dx.doi.org/10.1111/j.1741-6248.2006.00057.x

Wiseman, R. M., \& Gomez-Mejia, L. R. (1998). A behavioral agency model of managerial risk taking. Academy of Management Review, 23(1), 133-153.

Wright, P., Kroll, M., Lado, A., \& Ness, B. V. (2002). The structure of ownership and corporate acquisition strategies. Strategic Management Journal, 23(1), 41-53. http://dx.doi.org/10.1002/smj.208

Yang, Z. (2008). The moderating effect of group diversification on R\&D spillovers. The International Journal of Accounting Studies, 46, 31-65.

Yeh, Y. H., Lee, T. S., \& Woidtke, T. (2001). Family control and corporate governance: Evidence from Taiwan. International Review of Finance, 2(1), 21-48. http://dx.doi.org/10.1111/1468-2443.00014

Zahra, S. A. (2005). Entrepreneurial risk taking in family firms. Family Business Review, 18(1), 23-40. http://dx.doi.org/10.1111/j.1741-6248.2005.00028.x

\section{Notes}

Note 1. Upon Economic Cooperation Framework Agreement (ECFA) accession, Taiwan and Mainland China will both open up their finance and stock market, including banks, insurance and stock finance services. Other countries can enter one area first and then use the ECFA to enter both markets for the preferential policy.

Note 2. Since both cross-sectional and time series data are utilized, the Likelihood Ratio Test is first used to verify whether we should use the ordinary least squares, or PLS (Panel Least Squares) method for regression 
analysis. After that, the Hausman Test is used to determine whether fixed effects or random effects should be used in the estimation model. The results showed that the fixed effects model is superior to the ordinary least squares or random effect model.

\section{Copyrights}

Copyright for this article is retained by the author(s), with first publication rights granted to the journal.

This is an open-access article distributed under the terms and conditions of the Creative Commons Attribution license (http://creativecommons.org/licenses/by/3.0/). 